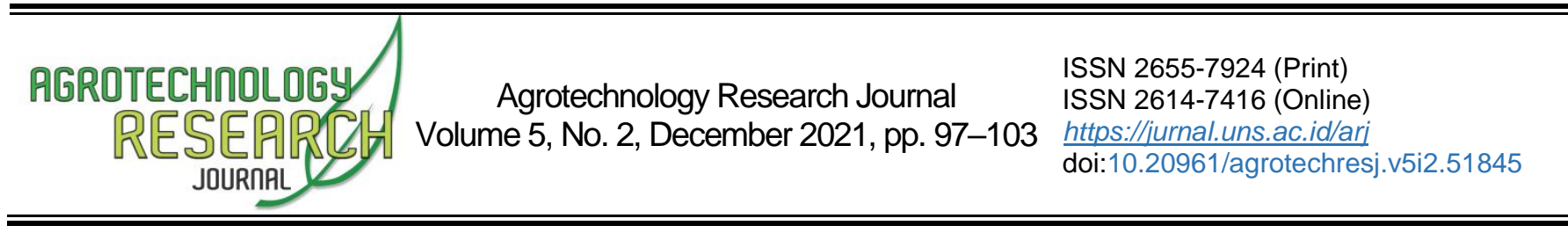

\title{
Pengaruh Ragam Jarak Tanam terhadap Pertumbuhan dan Produksi Sawi Hijau Organik
}

\section{Effect of Variety of Planting Distances on Growth and Production of Organic Green Mustard}

\author{
Muhammad Imam Nugraha ${ }^{1^{*}}$, Chatimatun Nisa ${ }^{2}$, Riza Adrianoor Saputra ${ }^{3}$ \\ ${ }_{1,3}$ Department of Agroecotechnology, Faculty of Agriculture, Universitas Lambung Mangkurat, Banjarbaru, Kalimantan Selatan, \\ 70714, Indonesia \\ ${ }^{2}$ Department of Agricultural Cultivation, Faculty of Agriculture, Universitas Lambung Mangkurat, Banjarbaru, Kalimantan Selatan, \\ 70714, Indonesia
}

Received 08 July 2021; Accepted 07 October 2021; Published 31 December 2021

\begin{abstract}
Modifying cultivation techniques potentially enhances mustard physical qualities to attain the demanded marketable value. The reputation of organic mustard propels farmers to implement modified cultivation techniques to improve harvest quality further. Planting space is one of the modifiable technical cultivations to achieve sustainable crop production. This research used soil planting media from acid dry land to optimize agricultural land use and cow manure as primary fertilizer to implement organic farming. This research objective is to figure the effect of different planting spaces on the growth and productivity of mustard greens that applied organic cultivation method. The preliminary arrangement of the research was a single-factor randomized block design. The factors were studied with

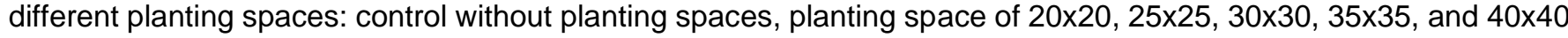
$\mathrm{cm} 2$. The outcomes revealed that the mean values of mustard green plant height $(13.38 \mathrm{~cm})$ and the number of leaves (9 strands) had significant differences to the control treatment $(10 \mathrm{~cm}$ plant height and seven strands number of leaf). The results showed that the optimum planting space of organic mustard cultivation was $40 \times 40 \mathrm{~cm} 2$ which achieved significantly higher plant height and the number of leaves than the control without planting spaces. This research's planting space of $40 \times 40 \mathrm{~cm} 2$ is appropriately suitable for monocropping systems in acid dry land. It can alter plant population and distribute environmental resources for sustaining crop growth and production.
\end{abstract}

Keywords: Brassica juncea; leaf width; number of leaves; plant height; productivity Cite this as (CSE Style): Nugraha MI, Nisa C, Saputra RA. 2021. Pengaruh ragam jarak tanam terhadap pertumbuhan dan produksi sawi hijau organik. Agrotechnology Res J. 5(2):97-103. https://dx.doi.org/10.20961/agrotechresj.v5i2.51845.

\section{PENDAHULUAN}

Masyarakat umum menggemari sayuran hijau yang terlihat segar dengan daun dan batang yang utuh. Sayuran dipilih oleh konsumen merupakan sayuran yang memiliki kesegaran dan kerenyahan. Kualitas sayuran sawi hijau dipengaruhi oleh nilai gizi, tekstur, kadar air dan penampilan fisik (Winarsih et al. 2012). BPS (2018) menyatakan bahwa Indonesia memproduksi sawi hijau terus mengalami peningkatan berturut-turut: 600.200 , $601.200,627.598$ dan 635.988 ton dari tahun 2015 hingga 2018.

Komponen-komponen fisik sawi hijau merupakan preferensi konsumen yang penting karena diharapkan dapat menghasilkan manfaat setelah dikonsumsi.

${ }^{*}$ Corresponding Author:

E-Mail': imam.nugraha@ulm.ac.id
Kecenderungan konsumen dalam memilih produk juga dipengaruhi oleh tingkat pendidikan (Noel 2009, Yasmin et al. 2017, Irsyad et al. 2018). Semakin tinggi tingkat pendidikan maka semakin spesifik untuk memilih bahan konsumsi. Konsumen dengan pendidikan tinggi cenderung beralih pada bahan konsumsi organik yang bebas dari bahan kimia sintesis (Sholihah dan Nurhidayati 2018).

Kualitas atribut sayur sawi mempengaruhi keputusan konsumen membeli bahan konsumsi. Aufanada et al. (2017) menyatakan variabel kualitas sayur daun organik seperti sawi, kangkung, selada sangat mempengaruhi kemauan konsumen membeli barang konsumsi berlabel organik. Kualitas sayur daun seperti sawi hijau, bayam dan kemangi yang memiliki total daun banyak, lebar dan tidak berlubang menjadi preferensi utama konsumen sayur organik (Yasmin et al. 2017, Irsyad et al. 2018, Yurlisa et al. 2018, Ramadhan 2020). Banyak petani beralih ke pertanian organik agar mendapatkan manfaat diantaranya harga jual tinggi, biaya produksi rendah dan 
keamanan harga pasar (Permana dan Widjayanthi 2019).

Kualitas fisik sawi yang baik dapat meningkatkan nilai jual (Yustina et al. 2017). Harga jual yang lebih tinggi mendorong petani melakukan budidaya sayur semi organik dengan tingkat motivasi mencapai 83,33\% (kategori tinggi) di Kelurahan Landasan Ulin Utara, Kota Banjarbaru (Yosidah et al. 2020). Budidaya sayur semi organik yaitu budidaya dengan komitmen mengurangi penggunaan pupuk ataupun pestisida kimia Pola peralihan ini perlu diiringi upaya peningkatan produk organik agar harga produk organik tetap terjaga.

Peningkatan kualitas fisik produk organik perlu rekayasa kultur teknis pengaturan jarak tanam selain dengan penambahan input organik (Purnama et al. 2013). Petani sawi jarang memanfaatkan jarak tanam dan acap kali hanya disebar. Petani sawi hijau masih belum menerapkan kultur teknis budidaya selaras dengan tolok ukur seperti aplikasi pupuk dengan sistem tabur, masih terikat erat dengan pupuk anorganik dan benih disebar tanpa jarak tanam sehingga populasi tanaman menjadi padat (Sangadji 2018). Jarak antar tanaman yang berdempetan mengakibatkan populasi tanaman yang tinggi dan menghambat laju pertumbuhan sehingga kualitas fisik tanaman menurun (Yulisma 2011).

Pengaturan jarak tanam dapat meningkatkan pertumbuhan tanaman sehingga kualitas fisik sayur sawi lebih baik. Sondhiya et al. (2019) menyatakan bahwa tinggi, jumlah batang maupun daun sawi hijau (Brassica juncea L.) meningkat secara signifikan pada setiap tahap pertumbuhan karena peningkatan jarak tanam hingga $60 \times 15 \mathrm{~cm}^{2}$ dibandingkan dengan jarak tanam lebih dekat. Usaha tani dalam pemeliharaan dan pembudidayaan tanaman sawi harus menyesuaikan dengan preferensi konsumen agar produksi sawi tersebut dapat terserap pasar dengan baik. Salah satu kultur teknis yang jarang dilakukan oleh petani sayur untuk mengoptimalkan pertumbuhan sayuran adalah penerapan jarak tanam.

Penelitian sebelumnya melakukan budidaya sawi pakcoy dengan sistem hidroponik dengan tujuan mengoptimalkan penggunaan lahan (Abror dan Arrohman 2019). Penelitian ini bermaksud mengoptimalkan lahan dengan cara berbeda yaitu menggunakan tanah di lahan kering masam sebagai media tanam untuk mengatasi keterbatasan lahan pertanian. Luas lahan kering masam di Kalimantan Selatan cukup luas sebesar 2.243 .490 ha dari total luas lahan kering yaitu 2.560 .733 ha sehingga sangat berpotensi untuk pemanfaatan pertanian (Ritung et al. 2015). Penelitian ini bertujuan untuk mengkaji efek variasi jarak tanam pada budidaya sawi hijau secara organik.

\section{BAHAN DAN METODE}

Percobaan ini dimulai dari bulan April-Mei 2019 di Kebun Percobaan Agroekoteknologi Fakultas Pertanian Universitas Lambung Mangkurat Banjarbaru ( $3^{\circ} 26^{\prime} 34,7^{\prime \prime}$ LS dan 114\%50'21,1" BT), Kecamatan Banjarbaru Selatan, tinggi tempat 7-100 mdpl (BPS Banjarbaru 2020). Hasil analisis data tanah awal tersaji pada Tabel 1.
Tabel 1. Kondisi fisik dan kimia tanah media tanam

\begin{tabular}{lcl}
\hline Parameter tanah & Nilai & \multicolumn{1}{c}{ Kriteria* $^{*}$} \\
\hline $\mathrm{pH}$ & 4,81 & Masam 4,5-5,5 \\
$\mathrm{C}(\%)$ & 0,49 & Sangat rendah $<1$ \\
$\mathrm{~N}(\%)$ & 0,97 & Sangat tinggi $>0,75$ \\
$\mathrm{P}_{2} \mathrm{O}_{5}$ Bray (ppm P) & 0,38 & Sangat rendah $<4$ \\
$\mathrm{KTK}(\mathrm{me} / 100 \mathrm{~g}$ tanah) & 3,37 & Sangat rendah $<5$ \\
$\mathrm{~K}(\mathrm{me} / 100 \mathrm{~g}$ tanah) & 0,27 & Rendah $0,1-0,3$ \\
$\mathrm{NH}_{4}(\mathrm{ppm})$ & 10,62 & Tinggi $>8$ \\
\hline
\end{tabular}

*Sumber: Eviati dan Sulaeman, 2009.

Tanah mengandung nitrogen $(\mathrm{N})$ tinggi berasal dari lahan yang sebelumnya sudah dipupuk $\mathrm{N}$. Bahan yang digunakan diantaranya: benih sawi hijau varietas Nauli F1 dan pupuk organik. Kultur organik adalah pupuk kotoran sapi yang sudah dikomposkan sebagai pupuk utama. Adapun alat yang digunakan untuk pengamatan pertumbuhan dan hasil tanaman sawi adalah penggaris dan timbangan.

Percobaan menggunakan Rancangan Acak Kelompok (RAK) Faktor Tunggal (jarak tanam terdiri dari 6 perlakuan), yakni:

(1) Kontrol (tanpa adanya jarak tanam)

(2) $20 \times 20 \mathrm{~cm}^{2}$

(3) $25 \times 25 \mathrm{~cm}^{2}$

(4) $30 \times 30 \mathrm{~cm}^{2}$

(5) $35 \times 35 \mathrm{~cm}^{2}$

(6) $40 \times 40 \mathrm{~cm}^{2}$

Setiap perlakuan diulang tiga kali, sehingga jumlah unit percobaan adalah 18 buah. Pelaksanaan percobaan sebagai berikut.

1. Panjang dan lebar petak $250 \times 200 \mathrm{~cm}$, sehingga luas petakan setara $5 \mathrm{~m}^{2}$ dan antar petak berjarak $30 \mathrm{~cm}$

2. Aplikasi pupuk utama 7-10 hari sebelum tanam, berupa pupuk organik kotoran sapi dengan dosis $2 \mathrm{~kg}$ $\mathrm{m}^{-2}$ yang setara dengan 20 t.ha $^{-1}$.

3. Media semai berupa campuran pupuk fermentasi cow manure dan tanah yang telah dihaluskan 1:1. Benih disebar kemudian ditimbun dengan media semai, berikutnya daun pisang diletakkan di atasnya sebagai tudung selama 2-3 hari seraya dilakukan penyiraman.

4. Bibit yang telah disemai berumur 7-10 hari dimasukkan dalam lubang tanam dengan jarak tanam sesuai perlakuan. Sulam dilakukan pada tanaman yang tidak tumbuh atau mati.

5. Pemanenan dilakukan pada umur 25-30 hari setelah tanam (HST). Kriteria panen Sayur sawi berdasarkan kualitas ukuran, bentuk dan warna daun.

Sebagai sampel pengamatan adalah 12 tanaman diamati pada satu, dua, dan tiga minggu setelah tanam (MST). Variabel pengamatan adalah:

1. Tinggi tanaman $(\mathrm{cm})$ diukur dari pangkal batang ujung daun terjauh.

2. Total daun (helai) sawi hijau yang tumbuh.

3. Lebar daun $(\mathrm{cm})$ diukur daun yang terlebar

4. Bobot segar (g.petak ${ }^{-1}$ ) sawi hijau dalam satu petakan.

5. Produksi merupakan konversi bobot segar sawi g. petak $^{-1}$ menjadi ton.ha ${ }^{-1}$. 
Data yang diperoleh dianalisis menggunakan sidik ragam (analysis of variance) dengan perangkat lunak Minitab 19 setelah uji kehomogenan Bartlet. Uji Beda Nyata Jujur (BNJ) dilakukan apabila jarak tanam berpengaruh secara signifikan $(p \leq 0,05)$ terhadap variabel pengamatan dengan taraf nyata $(\alpha) 5 \%$.

\section{HASIL DAN PEMBAHASAN}

Umur sawi hijau 3 MST pada jarak tanam $40 \times 40 \mathrm{~cm}^{2}$ menunjukkan respons tinggi tanaman yang signifikan jika dibandingkan dengan kontrol tanpa jarak dan 20x20 $\mathrm{cm}^{2}$. Perbedaan nyata tinggi tanaman terjadi pada 3 MST. Semakin lebar jarak tanam maka semakin besar intensitas cahaya yang dapat terdistribusi dan menyinari organ tanaman. Intensitas cahaya yang optimal dapat meningkatkan jumlah klorofil dan tinggi tanaman berbagai jenis sawi hijau. Intensitas cahaya 50\% menyebabkan tinggi tanaman, total daun, luas daun, berat basah akar, dan berat kering tanaman lebih tinggi dipadankan dengan intensitas cahaya $25 \%$ maupun $100 \%$. Efek ini dipengaruhi intensitas cahaya yang diterima dengan naungan $50 \%$ sesuai dengan kebutuhan sawi sehingga proses fotosintesis berjalan optimal (Wibowo et al. 2018). Jarak tanam lebih dekat maupun perlakuan tanpa jarak tanam pada penelitian ini mengakibatkan densitas tanaman lebih tinggi dari jarak $40 \times 40 \mathrm{~cm}^{2}$. Densitas tinggi dapat merepresi fotosintesis karena dapat menurunkan kandungan gula dan pati larut serta aktivitas enzim RuBP karboksilase (Dey et al. 2015). Yan et al. (2017) dalam penelitian juga menyebutkan bahwa densitas tanaman yang tinggi mengurangi kemampuan tanaman mengambil unsur nitrogen dalam tanah. Proses fotosintesis yang tertekan mengakibatkan pembentukan biomassa terhambat sehingga pertumbuhan tanaman menjadi kurang optimal (Li et al. 2019). Namun, apabila jarak tanam terlalu lebar juga mengurangi luas naungan yang terbentuk. Naungan yang cukup diperlukan agar fitohormon yang mengatur pertumbuhan tetap aktif saat tanaman mendapat radiasi matahari. Biosintesis fitohormon (seperti auksin dan sitokinin) terhambat apabila terkena paparan radiasi dengan intensitas cahaya tinggi dalam jangka panjang dan mengarah pada represi pertumbuhan tanaman (Huang et al. 2019). Jarak tanam $40 \times 40 \mathrm{~cm}^{2}$ pada penelitian ini memberikan naungan dan intensitas cahaya yang cukup untuk meregulasi fitohormon sehingga pertumbuhan tinggi tanaman meningkat secara signifikan. Tingkat fotosintesis yang optimal dengan intensitas cahaya cukup akan membentuk karbohidrat dan protein dalam jumlah besar sebagai sumber primer pertumbuhan sehingga meningkatkan tinggi tanaman (Lathifah dan Jazilah 2018).

Pertumbuhan tinggi tanaman pada 1 dan 2 MST belum menunjukkan perbedaan signifikan terhadap kontrol. Umur sawi hijau mempengaruhi kemampuan adaptasi tanaman terhadap kondisi lingkungan. Sarido dan Junia, (2017) menyatakan umur bibit sawi hijau 10 hari masih dalam tahap pertumbuhan awal sehingga akumulasi fotosintat banyak digunakan untuk beradaptasi dengan lingkungan. Pribadi et al. (2014) juga menyatakan bahwa pertumbuhan bibit pak choy yang berumur 20 hari lebih cepat dibandingkan bibit pak choy lebih muda pada tinggi tanaman, total dan luas daun. Parameter pertumbuhan total dan lebar daun memberikan pola peningkatan serupa pada satu sampai dengan dua MST dan hasil tertinggi juga terjadi pada tiga MST.

Tabel 2. Pengaruh jarak tanam terhadap tinggi sawi hijau umur tiga MST

\begin{tabular}{lc}
\hline Jarak tanam $\left(\mathrm{cm}^{2}\right)$ & Tinggi sawi hijau $(\mathrm{cm})^{*}$ \\
\hline $40 \times 40$ & $13,38^{\mathrm{a}}$ \\
$35 \times 35$ & $11,40^{\mathrm{ab}}$ \\
$30 \times 30$ & $11,16^{\mathrm{ab}}$ \\
$25 \times 25$ & $10,68^{\mathrm{ab}}$ \\
$20 \times 20$ & $10,13^{\mathrm{b}}$ \\
tanpa jarak & $9,88^{\mathrm{b}}$ \\
\hline${ }^{*}$ Keterangan: perbedaan notasi pada lajur yang sama menunjukkan
\end{tabular}

${ }^{*}$ Keterangan: perbedaan notasi pada lajur yang sama menunjukkan perbedaan signifikan menurut uji BNJ 5\%.

Sondhiya et al. (2019) menyatakan bahwa semua parameter pertumbuhan termasuk tinggi tanaman meningkat secara signifikan pada setiap tahap pertumbuhan sawi hijau karena peningkatan jarak tanam. Temuan ini menguatkan temuan dari banyak peneliti sebelumnya pada berbagai jenis tanaman hortikultura (Ngozi dan Chidera 2017; Thakur et al. 2018; Sondhiya et al. 2019). Zhai et al. (2018) menyatakan bahwa kompetisi intraspesifik tanaman berdampak buruk pada pertumbuhan dan perkembangan individu tanaman dalam suatu populasi. Tinggi sawi hijau makin tinggi seiring dengan jarak tanam semakin lebar (Tabel 2). Peningkatan jarak tanam memberikan ruang, sinar matahari, nutrisi dan kadar air tanah lebih tinggi sehingga aktivitas fotosintesis dan metabolisme semakin aktif memecah nutrisi menjadi energi dan membentuk (sintesis) senyawa metabolit primer untuk kebutuhan morfogenesis (Febriyono et al. 2017).

Jarak tanam $40 \times 40 \mathrm{~cm}^{2}$ menghasilkan total daun (9,53 helai) yang berbeda signifikan terhadap kontrol tanpa jarak. Dari jarak paling sempit $\left(20 \times 20 \mathrm{~cm}^{2}\right)$ hingga paling luas $\left(40 \times 40 \mathrm{~cm}^{2}\right)$ tidak berbeda nyata (Tabel 3). Temuan ini juga menguatkan hasil temuan total daun sebelumnya bahwa pertambahan lebar jarak tanam mengakibatkan total daun yang juga bertambah. Yordanova dan Nikolov (2017) melaporkan bahwa peningkatan jarak tanam mengurangi kepadatan individu tanaman dalam suatu lahan sehingga memberikan ruang tumbuh yang lebih baik untuk individu tanaman. Hasan et al. (2017) menyatakan jarak tanam optimal pada selada memberikan ruang yang cukup untuk pertumbuhan jumlah daun secara vertikal dan horizontal. Hasil pertambahan total daun pada Tabel 3. Semakin lebar jarak tanam maka semakin besar intensitas cahaya yang dapat digunakan oleh daun sebagai lokasi fotosintesis. Semakin banyak jumlah daun sawi maka semakin banyak pula karbohidrat yang dihasilkan. Karbohidrat inilah yang akan menunjang pertumbuhan dan perkembangan sawi (Cardoso et al. 2019). Pengaturan jarak tanam menjadi paradigma baru dalam produksi pertanian berkelanjutan. Solar Corridor Planting System (SCPS) adalah pengaturan dan metode penanaman baru yang mengatur ulang posisi spasial tanaman untuk memaksimalkan penangkapan radiasi matahari dan $\mathrm{CO}_{2}$ untuk meningkatkan pertumbuhan dan produksi tanaman (Kremer dan Deichman 2016, Hatfield dan Dold 2019). 
Tabel 3. Pengaruh jarak tanam terhadap total daun sawi hijau pada umur tiga MST

\begin{tabular}{lc}
\hline Jarak tanam $\left(\mathrm{cm}^{2}\right)$ & Total daun (helai) \\
\hline $40 \times 40$ & $9,53^{\mathrm{a}}$ \\
$35 \times 35$ & $8,72^{\mathrm{ab}}$ \\
$30 \times 30$ & $8,72^{\mathrm{ab}}$ \\
$25 \times 25$ & $8,28^{\mathrm{ab}}$ \\
$20 \times 20$ & $7,97^{\mathrm{ab}}$ \\
tanpa jarak & $6,89^{\mathrm{b}}$ \\
\hline
\end{tabular}

${ }^{*}$ Keterangan: perbedaan notasi pada lajur yang sama menunjukkan perbedaan bermakna menurut uji BNJ 5\%.

Pertumbuhan tinggi tanaman dan jumlah daun yang signifikan pada tiga MST disebabkan peran pupuk organik sebagai penyedia asam humat yang digunakan sebagai pupuk dasar dengan dosis dua $\mathrm{kg} \cdot \mathrm{m}^{-2}$. Abourayya et al. (2020) menyatakan peningkatan pertumbuhan vegetatif dapat dikaitkan dengan pengaruh asam humat pada tanaman dan tanah dalam meningkatkan aktivitas mikroba dan meningkatkan efektivitas tanah dalam serapan hara sebagai agen pengkelat dan stimulan pertumbuhan tanaman yang memperbaiki karakteristik vegetatif. Karima dan Oginawati (2020) menyatakan bahwa pupuk kompos padat kotoran sapi dengan dosis $4 \mathrm{~kg} \cdot \mathrm{m}^{-2}$ dapat meningkatkan pertumbuhan total daun sawi. Lebar daun merupakan indikator pertumbuhan yang penting karena berhubungan langsung dengan fotosintesis. VialetChabrand et al. (2017) di dalam penelitian menyebutkan tanaman dengan luas daun yang lebih besar memiliki kapasitas fotosintesis yang lebih besar karena penyerapan cahaya dan perolehan karbon lebih besar sehingga fiksasi karbon dapat maksimal. Kirschbaum (2011) menyatakan peningkatan fotosintesis dapat meningkatkan laju pertumbuhan relatif tanaman. Laju fotosintesis untuk tanaman yang tumbuh di bawah kondisi pertumbuhan optimal dapat mencapai lebih dari $50 \%$. Pertumbuhan lebar daun tersaji pada Gambar 1.

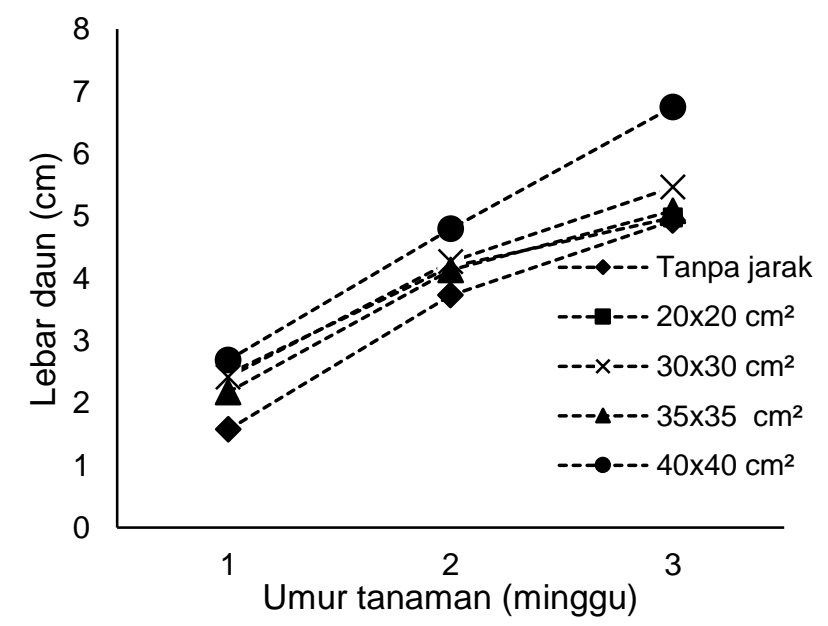

Gambar 1. Pertumbuhan lebar daun sawi hijau setiap minggu dengan disparitas jarak tanam

Jarak tanam tidak berpengaruh terhadap lebar daun pada semua pengamatan mingguan. Akan tetapi, jarak tanam dalam penelitian ini cenderung meningkatkan lebar daun sebesar $6,75 \mathrm{~cm}$ dari perlakuan jarak tanam 40x40 $\mathrm{cm}^{2}$ pada tiga MST. Abror dan Arrohman (2019) menyatakan jarak tanam paling lebar menghasilkan luas daun tanaman sawi pakcoi paling besar dan memiliki perbedaan signifikan terhadap jarak tanam lebih dekat. Jumlah tanaman yang tidak berlebihan dapat mengurangi kompetisi intraspesifik antar tanaman yang berdekatan seperti unsur hara, ruang tumbuh, cahaya dan air sehingga individu tanaman dapat memanfaatkan sumber daya tersebut dengan lebih baik. Niraula dan Timilsina (2020) menyatakan semakin lebar jarak tanam dalam suatu bedeng pembibitan maka semakin besar luas daun bibit sawi hijau yang akan ditanam. Pertumbuhan ini diduga ketersediaan cahaya lebih optimal sehingga menghasilkan lebih banyak akumulasi asimilat fotosintesis dalam daun dan menghasilkan pertumbuhan daun yang lebih baik.

Sawi hijau membutuhkan ruang tumbuh yang sesuai untuk menghasilkan bobot segar optimum. Hasil bobot segar akan mempengaruhi nilai konversi produktivitas tanaman hijau. Nilai bobot segar merupakan gambaran kemampuan tanaman dalam penyerapan air tersedia dan unsur hara. Perlakuan jarak tanam yang tepat dalam suatu budidaya tanaman akan memberikan ruang yang cukup agar akar dapat menyerap air dengan optimal sehingga bobot segar yang dipanen lebih maksimal (Febriyono et al. 2017). Hasil produktivitas tanaman yang dikonversi dari bobot segar pada penelaahan ini tidak signifikan. Hasil ini dapat ditelaah pada Gambar 2.

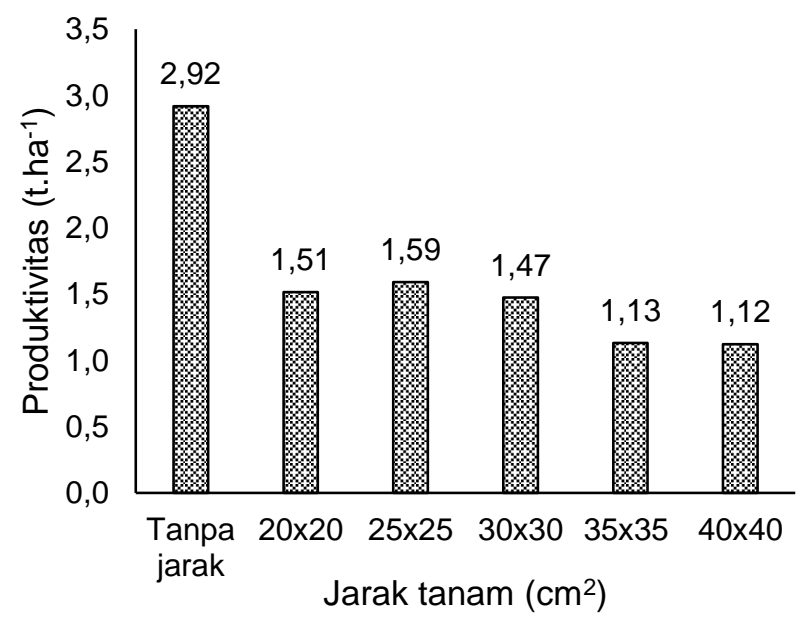

Gambar 2. Kapasitas produksi lahan sawi hijau dengan jarak tanam berbeda

Hasil ini menunjukkan kecenderungan produktivitas tanaman pada jarak $\left(40 \times 40 \mathrm{~cm}^{2}\right)$ memiliki produktivitas tanaman sawi paling rendah. Semakin lebar jarak tanam berdampak pada penurunan populasi tanaman sehingga bobot segar semakin rendah. Yulisma (2011) mengemukakan semakin lebar jarak tanam akan menurunkan populasi tanaman dan memberikan peluang perkembangan gulma, namun semakin rapat jarak tanam juga dapat menghambat pertumbuhan tanaman. Kumar et al. (2018) menyatakan semakin lebar pengaturan jarak tanam $\left(40 \times 25 \mathrm{~cm}^{2}\right)$ dapat mengurangi populasi tanaman dan berdampak negatif terhadap hasil panen. Jarak tanam $40 \times 25 \mathrm{~cm}^{2}$ pada tanaman Mustar India (Brassica juncea (L.) Czern.) memiliki populasi tanaman dan hasil panen lebih rendah daripada jarak tanam $60 \times 10 \mathrm{~cm}^{2}$ diselingi baris kosong $30 \mathrm{~cm}$ dengan sistem tanam jajar legowo. Rahman et al. (2019) 
menyatakan metode sebar tanpa jarak tanam memiliki populasi tanaman mustar Brassica campestris L. paling tinggi dibandingkan metode tanam dengan jarak 20x20 $\mathrm{cm}^{2}, 25 \times 25 \mathrm{~cm}^{2}$ maupun $30 \times 30 \mathrm{~cm}^{2}$. Metode sebar tanpa jarak tanam pada penelitian tersebut menghasilkan hasil panen paling tinggi sebesar 1,11 t.ha-1.

Hasil percobaan lebar daun dan produktivitas dalam penelitian ini tidak signifikan dengan peningkatan jarak tanam dibandingkan metode sebar. Hasil yang tidak berbeda signifikan ini kemungkinan disebabkan faktor genetis dari varietas sawi yang sangat mempengaruhi daya adaptasi dan respon pertumbuhan. Penelitian sebelumnya menyatakan bahwa faktor genotipe tanaman pada kondisi lingkungan yang sama dengan jarak tanam yang berbeda menyebabkan beberapa parameter pertumbuhan tidak mengalami perbedaan yang signifikan (Yetti dan Ardian 2010, Nasution et al. 2014, Sarido dan Junia 2017, Wahyudi 2020).

\section{KESIMPULAN DAN SARAN}

Jarak tanam 40x40 $\mathrm{cm}^{2}$ dengan budidaya secara organik pada penelitian ini mampu mencapai hasil optimal tinggi tanaman dan total daun sawi hijau yang berbeda secara signifikan terhadap kontrol tanpa jarak pada tiga MST. Pemberian dosis pupuk organik sebagai perlakuan perlu dipertimbangkan untuk penelitian selanjutnya agar rekayasa teknologi budidaya sawi hijau organik semakin efisien dan komprehensif.

\section{DAFTAR PUSTAKA}

Abourayya MS, Kaseem NE, Mahmoud TSM, Rakha AM, Eisa RA, Amin OA. 2020. Impact of soil application with humic acid and foliar spray of milagro bio-stimulant on vegetative growth and mineral nutrient uptake of nonpareil almond young trees under nubaria conditions. Bull Natl Res Cent. 44(1):1-8. https://doi.org/10.1186/s42269-020-00296-X.

Abror M, Arrohman JM. 2019. Perlakuan macam media tanam dan jarak tanam yang berbeda terhadap pertumbuhan tanaman sawi pakchoi (Brassica rapa L) dengan metode Hidroponik Sistem Wick. Nabatia. 16(1):35-42. doi:10.21070/nabatia.v16i1.453.

Aufanada V, Ekowati T, Prastiwi WD. 2017. Kesediaan membayar (Willingness to Pay) konsumen terhadap produk sayur organik di pasar modern Jakarta Selatan. Agrar J Agribus Rural Dev Res. 3(2):67-75. https://doi.org/10.18196/agr.3246.

[BPS] Badan Pusat Statistik. 2018. Statistik tanaman sayuran dan buah-buahan semusim indonesia, 2018. Subdirektorat Statistika Hortikultura, editor. Jakarta (ID): BPS RI.

[BPS Banjarbaru] Badan Pusat Statistik Kota Banjarbaru. 2020. Kecamatan Banjarbaru Selatan dalam Angka 2020. Banjarbaru (ID): BPS Kota Banjarbaru.

Cardoso F, Gomes DCBB, Viegas E. 2019. The influence of different types of manure and planting distance towards the growth and development of plants white mustard (Brassica juncea L.). Int J Dev Res. 09(1):25236-25245.
Dey S, North JA, Sriram J, Evans BS, Tabita FR. 2015. In Vivo studies in Rhodospirillum rubrum indicate that Ribulose-1,5-Bisphosphate Carboxylase/Oxygenase (Rubisco) catalyzes two obligatorily required and physiologically significant reactions for distinct Carbon and Sulfur metabolic pathways. J Biol Chem. 290(52):30658-30668. https://doi..org/10.1074/jbc.M115.691295.

Eviati, Sulaeman. 2009. Petunjuk teknis analisis kimia tanah, air dan pupuk. 2nd ed. Prasetyo BH, Santoso D, Widowati LR (Eds). Bogor (ID): Balai Penelitian Tanah.

Febriyono R, Susilowati YE, Suprapto A. 2017. Peningkatan hasil tanaman kangkung darat (Ipomoea reptans L.) melalui perlakuan jarak tanam dan jumlah tanaman per lubang. J IImu Pertan Trop Subtrop. 2(1):22-27.

Hasan MR, Tahsin AKMM, Islam MN, Ali MA, Uddain J. 2017. Growth and yield of lettuce (Lactuca Sativa L.) influenced as nitrogen fertilizer and plant spacing. IOSR J Agric Vet Sci. 10(6):62-71. https://doi.org/10.9790/2380-1006016271.

Hatfield JL, Dold C. 2019. Photosynthesis in the solar corridor system. In: The solar corridor crop system: Implementation and Impacts. Elsevier Inc. p1-33.

Huang J, Zhao X, Chory J. 2019. The arabidopsis transcriptome responds specifically and dynamically to high light stress resource the arabidopsis transcriptome responds specifically and dynamically to high light stress. Cell Rep. 29(12): 4186-4199.e3. https://doi.org/10.1016/j.celrep.2019.11.051.

Irsyad EP, Yoesdiarti A, Miftah H. 2018. Analisis persepsi dan preferensi konsumen terhadap atribut kualitas sayuran komersial di pasar modern. J Agribisains.

https://doi.org/10.30997/jagi.v4i2.1561.

$4(2): 1-7$.

Karima AN, Oginawati K. 2020. Utilization of livestock manure for fertilizer on mustard green and lettuce as an application of cleaner production. Res Environ Sci Eng. 1(2):54-60.

Kirschbaum MUF. 2011. Does enhanced photosynthesis enhance growth? lessons learned from $\mathrm{CO} 2$ enrichment studies. Plant Physiol. 155(1):117-124. https://doi.org/10.1104/pp.110.166819.

Kremer RJ, Deichman CL. 2016. The solar corridor: a new paradigm for sustainable crop production. Adv Plants Agric Res. 4(3):273-274. https://doi.org/10.15406/apar.2016.04.00136.

Kumar K, Kumar Y, Katiyar NK. 2018. Effect of plant geometry, nitrogen level and antitranspirants on physiological growth, yield attributes, WUE and economics of mustard (Brassica Juncea) under semiarid conditions of Western Uttar Pradesh. J Pharmacogn Phytochem. 7(2):226-229.

Lathifah A, Jazilah S. 2018. Pengaruh intensitas cahaya dan macam pupuk kandang terhadap pertumbuhan dan produksi tanaman sawi putih (Brassica pekinensia L.). Biofarm. 14(1):1-8. 
Li T, Zhang Y, Dai J, Dong H, Kong X. 2019. High plant density inhibits vegetative branching in cotton by altering hormone contents and photosynthetic production. F Crop Res. 230:121-131. https://doi.org/10.1016/j.fcr.2018.10.016.

Nasution AS, Awalluddin, Siregar MS. 2014. Pemberian pupuk ABG (Amazing Bio Growth) dan pupuk kompos terhadap pertumbuhan dan produksi tanaman sawi hijau (Brassica Juncea L. Coss). Agrium. 18(3):260-268.

Ngozi EA, Chidera VO. 2017. The effect of plant density on growth and yield of NsukkaYellow aromatic pepper (Capsicum annuum L.). African $\mathrm{J}$ Agric Res. 12(15):1269-1277. https://doi.org/10.5897/ajar2016.11923.

Niraula N, Timilsina A. 2020. Effects of seeding density on growth attributes of broadleaf mustard in nursery bed. Int J Appl Sci Biotechnol. 8(1):65-70. https://doi.org/10.3126/ijasbt.v8i1.28257.

Noel H. 2009. Consumer behaviour. Lausanne $(\mathrm{CH})$ : AVA Publishing SA.

Permana G, Widjayanthi L. 2019. Faktor pendorong anggota PATRA dalam mendukung pertanian organik di Desa Lombok Kulon Kecamatan Wonosari Kabupaten Bondowoso. In: Pembangunan pertanian dan peran pendidikan tinggi agribisnis: Peluang dan tantangan di era industri 4.0. Jember (ID): Universitas Jember. p511-516.

Pribadi GY, Roviq M, Wardiyanti T. 2014. Pertumbuhan dan produktivitas sawi pak choy (Brasica rapa L.) pada umur transplanting dan pemberian mulsa organik. J Produksi Tanam. 2(1):41-49.

Purnama RH, Santoso SJ, Hardiatmi S. 2013. Pengaruh dosis pupuk kompos enceng gondok dan jarak tanam terhadap pertumbuhan dan hasil tanaman sawi (Brassica juncea L.). INNOFARM J Inov Pertan. 12(2):95-107.

Rahman A, Islam MN, Fatima S, Rasal-Monir M, Kirtania M, Ahamed KU. 2019. Effect of different sowing methods and varieties on the yield of mustard (Brassica campestris L.). Int J Adv Agric Sci. 4(10):8-19.

Ramadhan RL. 2020. Preferensi konsumen terhadap atribut sayuran organik di kota Palembang. Skripsi. Palembang (ID): Universitas Sriwijaya.

Ritung S, Suryani E, Subardja D, Sukarman, Nugroho K, Suparto, Hikmatullah, Mulyani A, Tafakresnanto C, Sulaeman $Y$, et al. 2015. Sumber daya lahan pertanian Indonesia: luas, penyebaran dan potensi ketersediaan. Husen E, Agus F, Nursyamsi D (Eds). Bogor (ID): IAARD Press.

Sangadji Z. 2018. Kajian sistem budidaya tanaman sawi (Brassica juncea L.) di petani Kelurahan Malawele Distrik Aimas Kabupaten Sorong. Median J IImu-IImu Eksakta. https://doi.org/10.33506/md.v9i1.312.
Sarido L, Junia. 2017. Uji Pertumbuhan dan hasil tanaman pakcoy (Brassica rapa L.) dengan pemberian pupuk organik cair pada sistem hidroponik. AGRIFOR. 16(1):65-74.

Sholihah A, Nurhidayati N. 2018. IbM Kelompok Tani Hortikultura dalam rangka perbaikan manajemen produksi kompos. JIPEMAS. 1(2):94.

Sondhiya R, Pandey R, Namdeo KN. 2019. Effect of plant spacings on growth, yield and quality of mustard (Brassica juncea L.) genotype. Ann Plant Soil Res. 21(2):172-176.

Thakur G, Singh AK, Maurya PK. 2018. Effect of plant spacing on fruit quality of capsicum (Capsicum annuum L) hybrid buffalo under natural ventilated polyhouse. Int J Curr Microbiol Appl Sci. 7(05):298302. https://doi.org/10.20546/ijcmas.2018.705.038.

Vialet-Chabrand S, Matthews JSA, Simkin AJ, Raines CA, Lawson T. 2017. Importance of fluctuations in light on plant photosynthetic acclimation. Plant Physiol. 173(4):2163-2179. https://doi.org/10.1104/pp.16.01767.

Wahyudi D. 2020. Pengaruh jarak tanam dan pemberian pupuk SP-36 terhadap pertumbuhan dan produksi tanaman padi sawah (Oryza Sativa L.). Medan (ID): Universitas Muhammadiyah Sumatera Utara.

Wibowo SA, Sunaryo Y, Pamungkas DH. 2018. Pengaruh pemberian naungan dengan intensitas cahaya yang berbeda terhadap pertumbuhan dan hasil berbagai jenis tanaman sawi (Brassica juncea L.). Agroust. 2(1).

Winarsih D, Prihastanti E, Saptiningsih E. 2012. Kadar serat dan kadar air serta penampakan fisik produk pascapanen daun caisim (Brassica juncea L.) yang ditanam pada media dengan penambahan pupuk organik hayati cair dan pupuk anorganik. Bioma. 14(1): 25-32. https://doi.org/10.14710/bioma.14.1.25-32.

Yan P, Pan J, Zhang W, Shi J, Chen X, Cui Z. 2017. A High plant density reduces the ability of maize to use soil nitrogen. PLoS One. 12(2):1-12. https://doi.org/10.1371/journal.pone.0172717.

Yasmin TR, Prastiwi WD, Handayani M. 2017. Analisis konjoin preferensi konsumen sayuran hidroponik agrofarm bandungan Kabupaten Semarang. Agrisocionomics J Sos Ekon Pertan. 1(1):85-93. https://doi.org/10.14710/agrisocionomics.v111.1643.

Yetti H, Ardian. 2010. Pengaruh penggunaan jarak tanam terhadap tertumbuhan dan produksi padi sawah (Oryza sativa L.) varietas IR 42 dengan metode SRI (System of Rice Intensification). SAGU. 9(1):21-27.

Yordanova M, Nikolov A. 2017. influence of plant density and mulching on growth and yield of lettuce (Lactuca sativa var. romana L.). Int J Environ Agric Res. 3(10):10-14. https://doi.org/10.25125/agriculturejournal-ijoear-oct-2017-1. 
Yosidah A, Fajeri H, Septiana N. 2020. Tingkat motivasi petani sayur pada budidaya sayur semi organik dan sayur anorganik di Kelurahan Landasan Ulin Utara, Kota Banjarbaru. Front Agribisnis. 4(2):98-107.

Yulisma. 2011. Pertumbuhan dan hasil beberapa varietas jagung pada berbagai jarak tanam. J Penelit Pertan Tanam Pangan. 30(3):196-203.

Yurlisa K, Maghfoer MD, Aini N, Sumiya Dwi Yamika W. 2018. Preferensi konsumen terhadap atribut kualitas tiga jenis sayuran indigenous di Jawa Timur, Indonesia. J Hortik Indones. 9(3):158-166. https://doi.org/10.29244/jhi.9.3.158-166.
Yustina I, Sa'adah Z, Aziz FN. 2017. Kajian kualitas pasca panen sawi (Brassica Juncea L.) yang dipupuk menggunakan tiga jenis pupuk kandang dan urea. In: Hurasan S, Male D, Raharjo SHT, Jambornias E, Putuhuru F, Matitaputty PR, Hidayah I, Alfons JB (Eds). Mewujudkan Kedaulatan Pangan pada Lahan Sub Optimal Melalui Inovasi Teknologi Pertanian Spesifik Lokasi. Bogor (ID): Balai Besar Pengkajian dan Pengembangan Teknologi Pertanian. p523-528.

Zhai L, Xie R, Ming B, Li S, Ma D. 2018. Evaluation and analysis of intraspecific competition in maize: A case study on plant density experiment. J Integr Agric. 17(10):2235-2244. https://doi.org/10.1016/S20953119(18)61917-3. 